\title{
L-Type Calcium Channels Mediate a Slow Excitatory Synaptic Transmission in Rat Midbrain Dopaminergic Neurons
}

\author{
Antonello Bonci, ${ }^{1}$ Pernilla Grillner, ${ }^{1}$ Nicola B. Mercuri, ${ }^{1,2}$ and Giorgio Bernardi ${ }^{1,2}$ \\ 1 Ístituto Ricovero e Cura a Carattere Scientifico Santa Lucia, 00179 Rome, Italy, and ${ }^{2}$ Clinica Neurologica, University of \\ Tor Vergata, 00173 Rome, Italy
}

Patch pipettes were used to record whole-cell synaptic currents under voltage-clamp in dopaminergic neurons in slices of rat substantia nigra pars compacta and ventral tegmental area. We report that dihydropyridines (DHPs), L-type $\mathrm{Ca}^{2+}$ channel

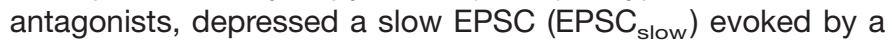
train of focally delivered electrical stimuli. In fact, the amplitude of the $\mathrm{EPSC}_{\text {slow }}$ was reduced by the DHP antagonists nifedipine $(1-100 \mu \mathrm{M})$, nimodipine $(1-100 \mu \mathrm{M})$, and isradipine (30 $\mathrm{nM}-100 \mu \mathrm{M})$ in a concentration-dependent and reversible manner. On the other hand, Bay-K $8644(1 \mu \mathrm{M})$, an L-type $\mathrm{Ca}^{2+}$

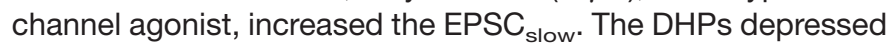
the $\mathrm{EPSC}_{\text {slow }}$ only when the high-frequency stimulation that was used to evoke this synaptic current lasted $>70$ msec. On the other hand, Bay-K 8644 increased the amplitude of the EPSC $_{\text {slow }}$ only when it was evoked by a train $<70 \mathrm{msec}$. Moreover, the DHPs did not affect the EPSC $\mathrm{Fast}_{\text {, the }} \mathrm{IPSC}_{\text {fast }}$, and the IPSC slow $_{\text {. The inhibition of the EPSC }}$ slow caused by the
DHPs is attributed to presynaptic mechanisms because (1) the inward current generated by exogenously administered glutamate was not affected and (2) the $\mathrm{EPSC}_{\text {slow }}$ was reduced to a similar degree even when the activation state of postsynaptic L-type $\mathrm{Ca}^{2+}$ channels was changed by holding the neurons at $-100,-60$, and $+30 \mathrm{mV}$. Finally, a DHP-sensitive component of the $\mathrm{EPSC}_{\text {slow }}$ could even be detected after the blockade of $\mathrm{N}-, \mathrm{Q}^{-}$, and P-type $\mathrm{Ca}^{2+}$ channels by the combination of $\omega$-conotoxin GVIA, $\omega$-agatoxin IVA, and $\omega$-conotoxin MVIIC. Taken together, these results indicate that under certain patterns of synaptic activity, L-type $\mathrm{Ca}^{2+}$ channels regulate the synaptic release of excitatory amino acids on the dopaminergic neurons of the ventral mesencephalon.

Key words: dopamine neurons; L-type calcium channels; dihydropyridines; excitatory postsynaptic currents; midbrain; electrophysiology
The increase of calcium influx into the presynaptic terminal is generally considered a fundamental event that triggers neurotransmitter release (Katz and Miledi, 1969; Llinàs et al., 1981; Augustine et al., 1987). Several types of presynaptic calcium channels, particularly the $\mathrm{N}$-type and $\mathrm{P} / \mathrm{Q}$-type, have been thought to participate in calcium-mediated neurotransmitter secretion (Bean, 1989; Seabrook and Adams, 1989; Mintz et al., 1992; Luebke et al., 1993; Wheeler et al., 1994; Dunlap et al., 1995; Wright and Angus, 1996). Despite observations that L-type calcium channels play an important role in the release of neurotransmitters such as catecholamines from chromaffin cells, dynorphin from the dendrites of rat hippocampal granule cells, neuropeptides from the neurohypophysis, and excitatory amino acids (EAAs) from the retina (Lemos and Nowycky, 1989; Takibana et al., 1993; Lopez et al., 1994; Simmons et al., 1995; Von Gersdorff and Matthews, 1996), these channels are thought to play a minor role in most neuronal excitation-secretion events. In fact, it is generally thought that they are not active during the generation of action potentials in the CNS and the subsequent depolarization of the synaptic terminals (Miller, 1987; Kullman et al., 1992; Dunlap et al., 1995; Reuter, 1996). Consistent with these findings, the inhibition of L-type $\mathrm{Ca}^{2+}$ channels has little effect on synap-

\footnotetext{
Received April 24, 1998; revised June 12, 1998; accepted June 16, 1998.

We thank Robert C. Malenka, Thomas Knopfel, and Bruce P. Bean for their helpful comments and M. Federici for the technical assistance.

Correspondence should be addressed to Nicola B. Mercuri, Experimental Neurology Laboratory, Ístituto Ricovero e Cura a Carattere Scientifico Santa Lucia, Via Ardeatina 306, 00179 Roma, Italy.

Dr. Bonci's present address: Department of Psychiatry and Physiology, School of Medicine, University of California, 401 Parnassus Avenue, San Francisco, CA 94143. Copyright (C) 1998 Society for Neuroscience $0270-6474 / 98 / 186693-11 \$ 05.00 / 0$
}

tic transmission in areas such as the frontal cortex, hippocampus, accumbens, cerebellum, and striatum (Kamiya et al., 1988; Llinàs et al., 1989; Horne and Kemp, 1991; Kullman et al., 1992; Mintz et al., 1992; Turner et al., 1992; Zhang et al., 1993; Wheeler et al., 1994). In the present study, we report a specific modulation by L-type $\mathrm{Ca}^{2+}$ channels of slow EPSCs $\left(\mathrm{EPSCs}_{\text {slow }}\right)$ evoked under voltage-clamp on presumed dopamine-containing neurons of the rat midbrain, by using the whole-cell patch-clamp technique (Wu et al., 1995; Bonci and Williams, 1997; Shen and Johnson, 1997). This slow synaptic excitatory event, generated by the activation of NMDA and metabotropic receptors (Mercuri et al., 1996; Shen and Johnson, 1997), is likely caused by the release of aspartate/ glutamate from inputs to the midbrain arising from the cortex, subthalamus, and pedunculopontine nucleus (Christie et al., 1985; Kita and Kitai, 1987; Sesack and Pickel, 1992; Lavoie and Parent, 1994). Given the considerable evidence that the dopaminergic neurons influence various motor and behavioral states (Le Moal 1995), a regulation of their excitatory afferents by L-type $\mathrm{Ca}^{2+}$ channels is an important topic that might have physiological and therapeutic implications (Seeman, 1995).

\section{MATERIALS AND METHODS}

Preparation of the tissue. Male albino Wistar rats (150-300 gm) were killed under halothane anesthesia. The preparation of the slices has been described previously (Mercuri et al., 1995). Briefly, a single horizontal slice (200-350 $\mu \mathrm{m}$ thick) containing the substantia nigra and the ventral tegmental area was transferred to a recording chamber and continuously perfused at a rate of $2.5 \mathrm{ml} / \mathrm{min}$, with a solution maintained at $35^{\circ} \mathrm{C}$ and oxygenated with a mixture of $95 \% \mathrm{CO}_{2} / 5 \% \mathrm{O}_{2}$. The standard solution contained (in mM): $\mathrm{NaCl} 126, \mathrm{KCl} 2.5, \mathrm{NaH}_{2} \mathrm{PO}_{4} 1.2, \mathrm{MgCl}_{2} 1.2, \mathrm{CaCl}_{2}$ 2.4, glucose 11, and $\mathrm{NaHCO}_{3} 19$, giving a $\mathrm{pH}$ of 7.4 . 


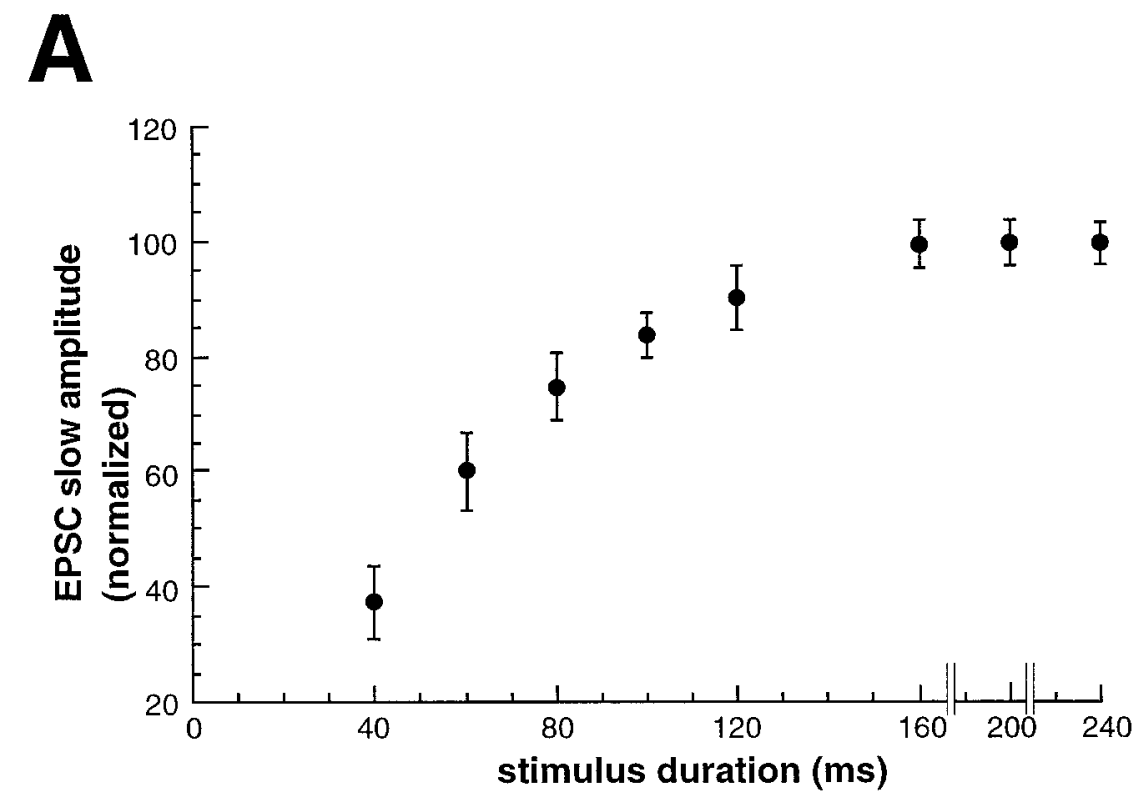

B

a

b is dependent on the duration of the train. The amplitude of the synaptic current was measured after the stimulation. Each point represents at least three experiments. $B a$, The NMDA antagonist APV depresses the EPSC $_{\text {slow }}$ in a reversible manner, whereas the AMPA/kainate antagonist CNQX $(10 \mu \mathrm{M})$ did not produce any effect on the

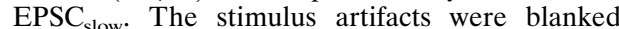
(records are average of 4 sweeps). $\mathrm{Bb}$, The metabotropic antagonist $(+)-\mathrm{MCPG}(300 \mu \mathrm{M})$ also depresses the $\mathrm{EPSC}_{\text {slow }}$ in a reversible manner.

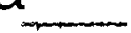

\section{D-APV $(50 \mu \mathrm{M})$}

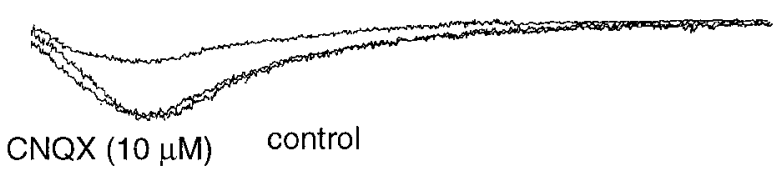

CNQX $(10 \mu \mathrm{M}) \quad$ control

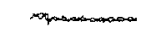

$(+)-M C P G(300 \mu \mathrm{M})$

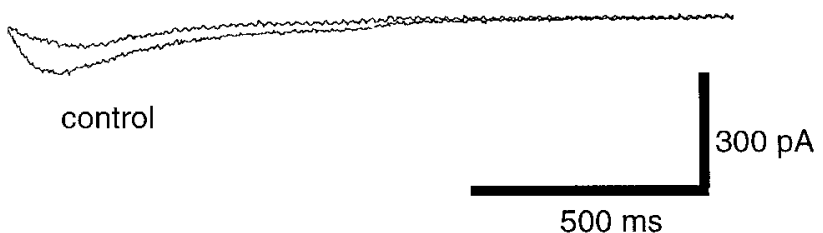

Recording and stimulation. The slice was transferred to a recording chamber on the stage of an upright microscope (Axioscope, Carl Zeiss) illuminated with infrared light. The presumed dopaminergic neurons were directly visualized and approached by positive pressure. Whole-cell recordings were made using patch pipettes having a resistance of 4-7 $\mathrm{M} \Omega$ and containing (in $\mathrm{mM}$ ): potassium gluconate $144, \mathrm{CaCl}_{2} 0.3, \mathrm{MgCl}_{2}$ 1.2, HEPES 10, EGTA 1, Mg-ATP 2, and GTP 0.25, pH 7.3. To record the IPSC $_{\text {fast }}, 128 \mathrm{~mm} \mathrm{KCl}$ and $20 \mathrm{~mm} \mathrm{NaCl}$ were used instead of potassium gluconate. In the experiments with the neurons clamped at -100 and $+30 \mathrm{mV}$, the intracellular solution contained $120 \mathrm{~mm}$ cesium gluconate instead of potassium gluconate, whereas during the recordings at $30 \mathrm{mV}$ the internal solution also contained the sodium channel blocker QX-314 (10 mM). The series resistance compensation was usually set at $80 \%$, and the series resistance $\left(R_{\mathrm{s}} 5-16 \mathrm{M} \Omega\right)$ was monitored during the experiments every time an EPSC was evoked. The neurons were voltageclamped using an Axopatch-1D amplifier (Axon Instruments, Foster City, CA). The synaptic events were evoked with bipolar tungstenstimulating electrodes positioned in the ventral mesencephalon $(200-400$ $\mu \mathrm{m}$ from the recording site). All of the electrical stimuli were locally

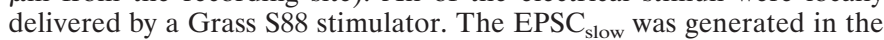
dopaminergic neurons by a repetitive electrical stimulation $(100-300 \mathrm{~Hz}$, 40-400 msec duration, 1-20 V, delivered at $45 \mathrm{sec}$ intervals). To evoke

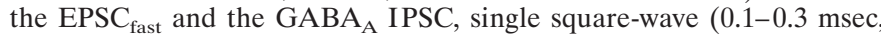
$1-10 \mathrm{~V}$,) pulses were applied every $20 \mathrm{sec}$. In experiments examining the EPSC $_{\text {slow }}$ and the EPSC $_{\text {fast }}$, the superfusion medium contained picrotoxin $(100 \mu \mathrm{M})$ or bicuculline $(30 \mu \mathrm{M})$, saclofen $(300 \mu \mathrm{M})$, and strychnine $(1 \mu \mathrm{M})$, to block $\mathrm{GABA}_{\mathrm{A}}, \mathrm{GABA}_{\mathrm{B}}$, and glycine receptors, respectively. The $\mathrm{GABA}_{\mathrm{A}}$ IPSC was evoked in the presence of DL-2-amino-5phosphono-pentanoic acid (APV) $(30 \mu \mathrm{M})$ and 6-cyano-7nitroquinoxaline-2,3-dione (CNQX) $(10 \mu \mathrm{M})$ to block NMDA and AMPA/kainate receptors, respectively. A stimulation protocol similar to

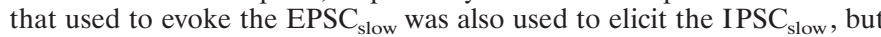
the superfusing solution contained picrotoxin $(100 \mu \mathrm{M})$ or bicuculline (30 $\mu \mathrm{M})$, APV $(30 \mu \mathrm{M})$, and CNQX $(10 \mu \mathrm{M})$. The synaptic currents were captured and stored on a computer by using the Pclamp software 6.0.3 (Axon Instruments) and the analog/digital Maclab Chart software (AD 
A

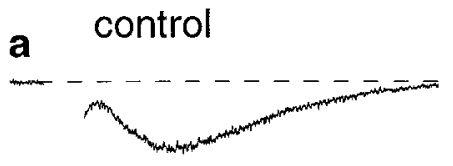

nifedipine $(3 \mu \mathrm{M})$

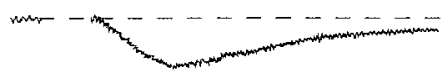

wash

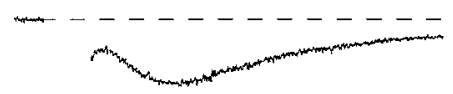

nifedipine $(3 \mu \mathrm{M})$

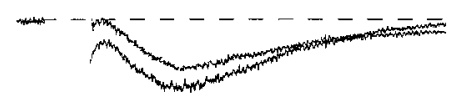

B

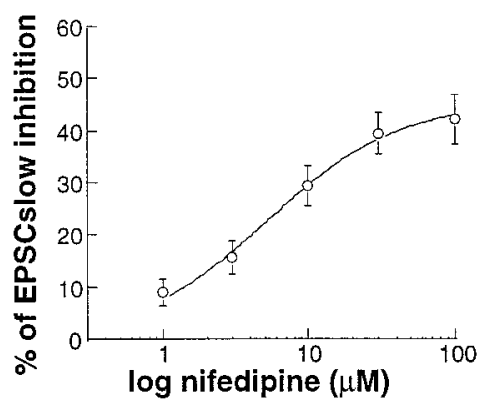

b

control

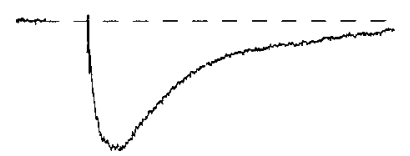

nimodipine $(10 \mu \mathrm{M})$

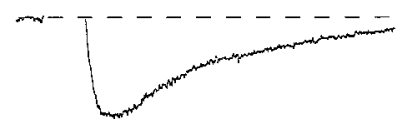

wash

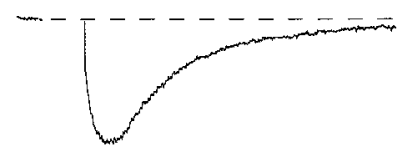

nimodipine $(10 \mu \mathrm{M})$
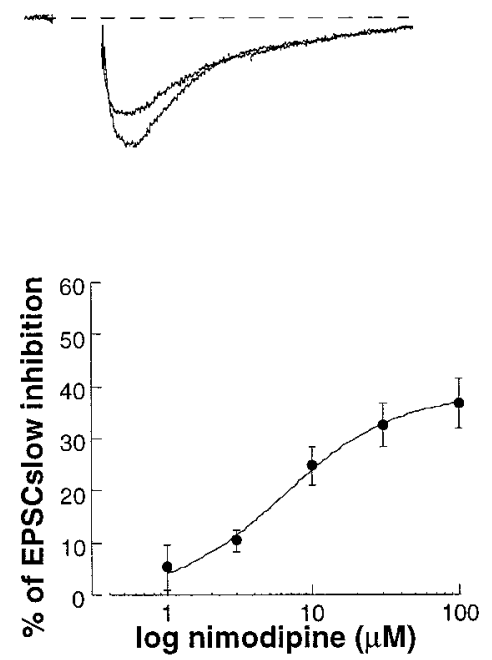

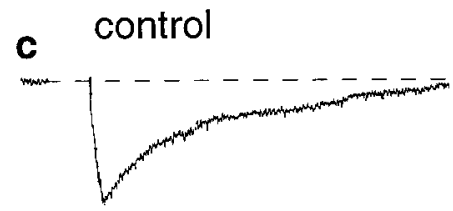

isradipine $(1 \mu \mathrm{M})$

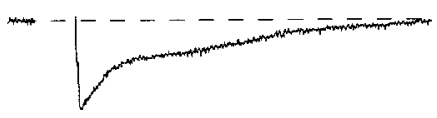

wash

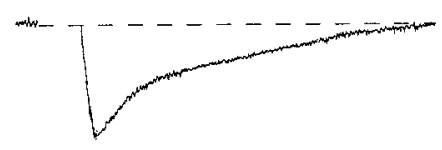

isradipine $(1 \mu \mathrm{M})$
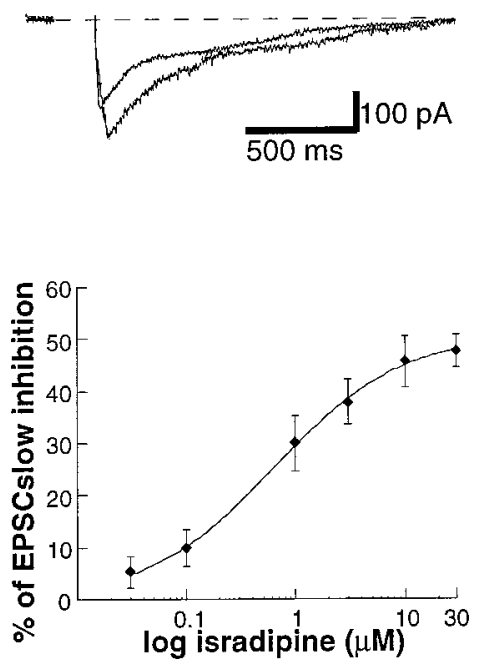

Figure 2. Effects of dihydropyridines on the slow excitatory synaptic transmission. The traces represent the EPSC slow $_{\text {in }}$ control, during and after (wash) the effect of nifedipine $(3 \mu \mathrm{M})$, nimodipine $(10 \mu \mathrm{M})$, and isradipine $(1 \mu \mathrm{M})$. The bottom traces in $A a, A b$, and $A c$ are superimposed (control vs the effect of the $\mathrm{L}$-type $\mathrm{Ca}^{2+}$ antagonists). $B$, Dose-response plots of the inhibition of the $\mathrm{EPSC}_{\text {slow }}$ caused by nifedipine (left), nimodipine (middle), and isradipine $($ right $)$. Each point is an average of at least four different experiments. Only one experiment per slice was performed. To calculate the percentage inhibition of the $\mathrm{EPSC}_{\text {slow }}$, each cell was taken as its own control.

Instruments, Castle Hill, Australia). The $\mathrm{EPSC}_{\text {slow }}$ amplitude was measured by averaging a period of $10 \mathrm{msec}, 400 \mathrm{msec}$ after the end of the train of stimuli. The data were subsequently analyzed with an Axograph 3.0 (Axon Instruments). The dose-response curves of the effects of the drugs and the statistical analyses were performed by using Kaleidograph, Mac Draw, and Stat View 4.1 running on a MacIntosh computer.

Application of drugs. The drugs were bath-applied at a defined concentration. Drug solutions entered the recording chamber no later than 20 $\mathrm{sec}$ after a three-way tap was turned. Complete replacement of the medium in the chamber took $90 \mathrm{sec}$. In some experiments, glutamate $(1$ mM) was applied via a puffer pipette $(20-80 \mathrm{msec}, 100-200 \mathrm{kPa})$ controlled by a Picrospritzer II (General Valve Corporation, Fairfield, NJ) and placed $\sim 50 \mu \mathrm{m}$ above the recorded cells. The following drugs were used: picrotoxin, bicuculline methiodide, methionine enkephalin, dopamine, nifedipine, and APV [all obtained from Sigma (St. Louis, MO)]. CNQX, $( \pm)$ - $\alpha$-methyl-4-carboxyphenylglycine (MCPG), and 2-hydroxy- saclofen (saclofen) were obtained from Tocris Cookson. Nimodipine and Bay-K 8644 were a gift from Bayer Italia. Isradipine was obtained from Sandoz (Basel, Switzerland), and $\omega$-conotoxin GVIA, $\omega$-agatoxin-IVA, and $\omega$-conotoxin MVIIC were obtained from Alomone Labs.

\section{RESULTS}

Properties of the dopaminergic neurons and characterization of the slow synaptic currents

The "principal" or presumed dopaminergic neurons of the midbrain were identified by their spontaneous firing, broad $(>1.5 \mathrm{msec}$ ) action potentials (under current-clamp), a pronounced hyperpolarization-activated inward rectification $\left(I_{\mathrm{h}}\right)$, an outward current response to dopamine $(10-30 \mu \mathrm{M})$, and no outward current to the superfusion of methionine enkephalin 
A
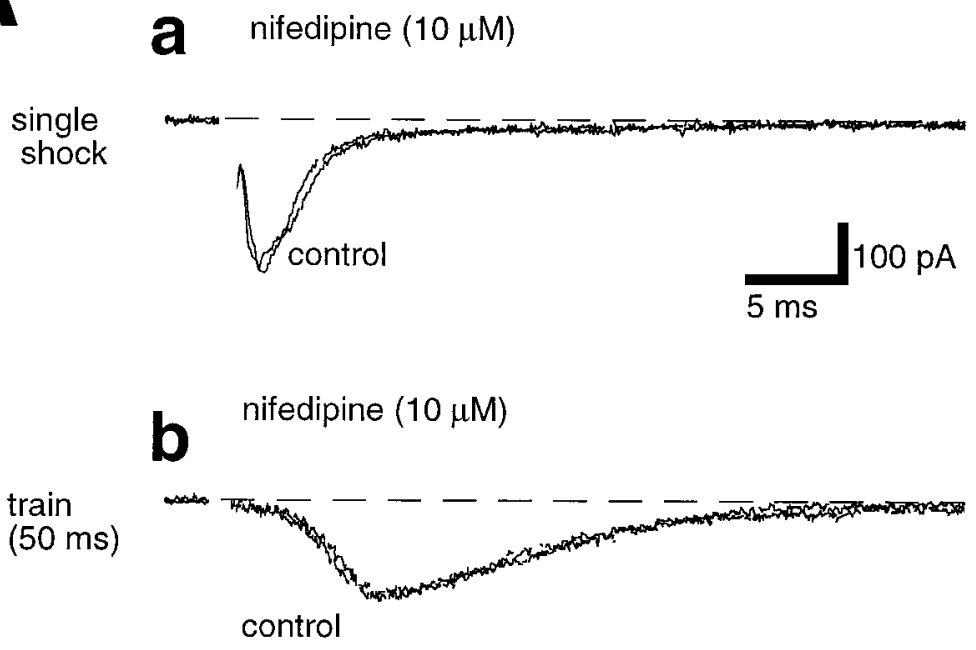

C nifedipine $(10 \mu \mathrm{M})$

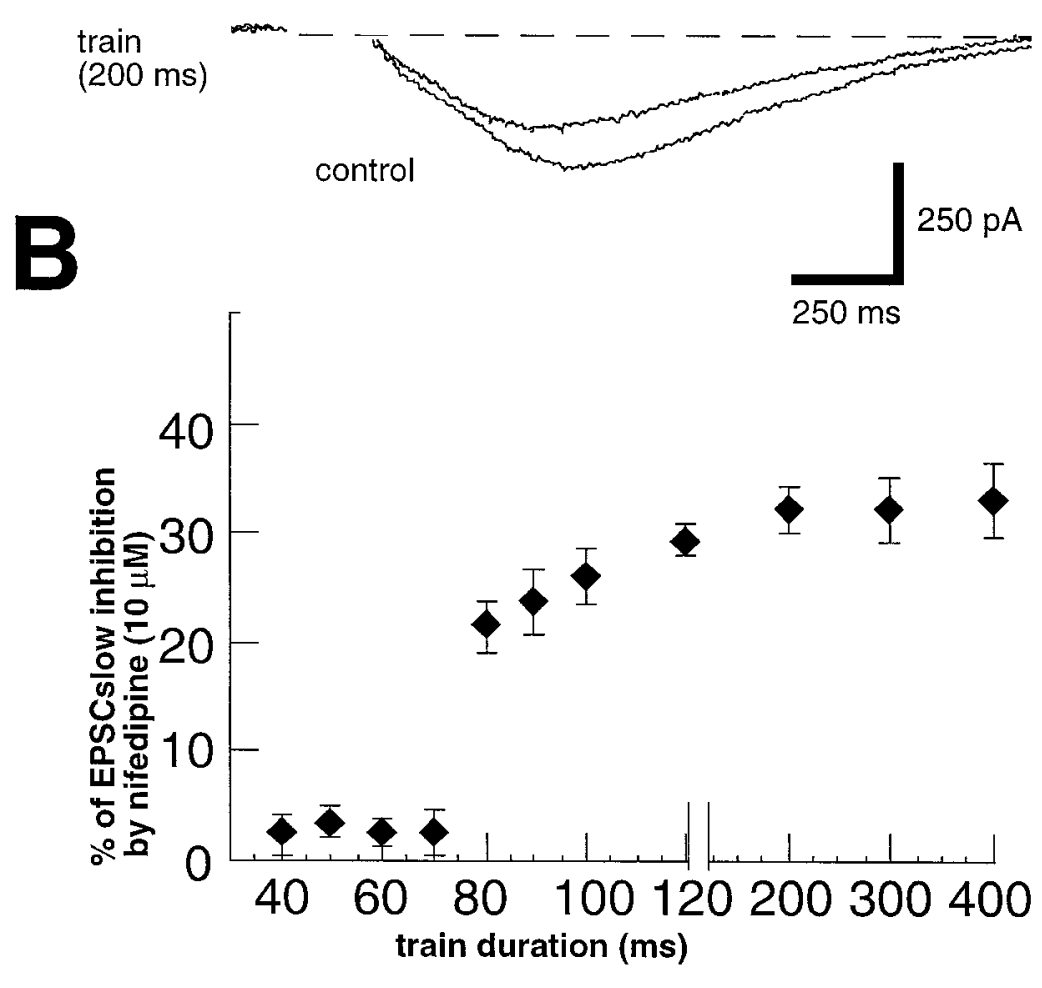

Figure 3. $A$, The percentage of inhibition of the $\mathrm{EPSC}_{\text {slow }}$ caused by nifedipine is dependent on the duration of the electrical stimulation. $A a$, Superimposed EPSC $_{\text {fast }}$ in control condition and after the application of nifedipine. $A b, A c$, A 50 msec and a $200 \mathrm{msec}$ train of stimuli were delivered to evoke

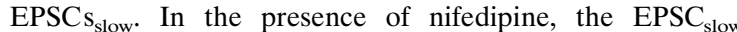
evoked by the longer train $(c)$ was depressed, but the EPSC evoked by the short train $(b)$ was not affected. The time and current bars in $c$ are also valid for $b$. Note that the $\mathrm{EPSC}_{\text {fast }}$ in $a$ and the EPSC $C_{\text {slow }}$ in $c$ were elicited alternately in the same neuron. $B$, The graph shows that the depression of the EP$\mathrm{SC}_{\text {slow }}$ caused by nifedipine $(10 \mu \mathrm{M})$ is dependent on the duration of the electrical stimulus.

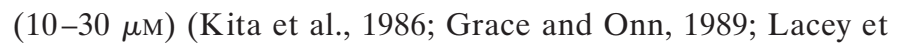
al., 1989; Yung et al., 1991; Johnson and North, 1992; Mercuri et al., 1995).

The local stimulation of the ventral mesencephalon by a train of electrical stimuli determined an EPSC $\left(\mathrm{EPSC}_{\text {slow }}\right)$ in cells patch-clamped at $-60 \mathrm{mV}$. Figure $1 A$ shows that the size of the EPSC $_{\text {slow }}$ was dependent on the duration of the train. It is clear that $150-200 \mathrm{msec}$ are necessary to fully generate the $\mathrm{EPSC}_{\text {slow }}$ for a given train of stimuli. The maximal amplitude and the mean duration of the $\mathrm{EPSC}_{\text {slow }}$ was $371 \pm 16.2 \mathrm{pA}(n=$
$60)$ and $2.12 \pm 0.8 \mathrm{sec}(n=20)$, respectively. The EPSC slow $_{\text {was }}$ caused by the coactivation of NMDA and metabotropic EAA receptors (Mercuri et al., 1996; Shen and Johnson, 1997). In fact, the application of the non-NMDA receptor antagonist CNQX $(10 \mu \mathrm{M})$ did not modify the amplitude of the EPSC $\mathrm{Slow}_{\text {slow }}$ $(n=6)$ (Fig. $1 B a)$. In addition, the NMDA receptor antagonist APV $(30 \mu \mathrm{M})$ depressed this synaptic event by $59 \pm 4.1 \%(n=$ 11) (Fig. 1 $\mathrm{Ba}$ ), whereas the nonspecific metabotropic receptors antagonist MCPG $(300 \mu \mathrm{M})$ depressed the $\mathrm{EPSC}_{\text {slow }}$ by $34.9 \pm$ $5.9 \%(n=9)$ (Fig. $1 B b)$. 
A
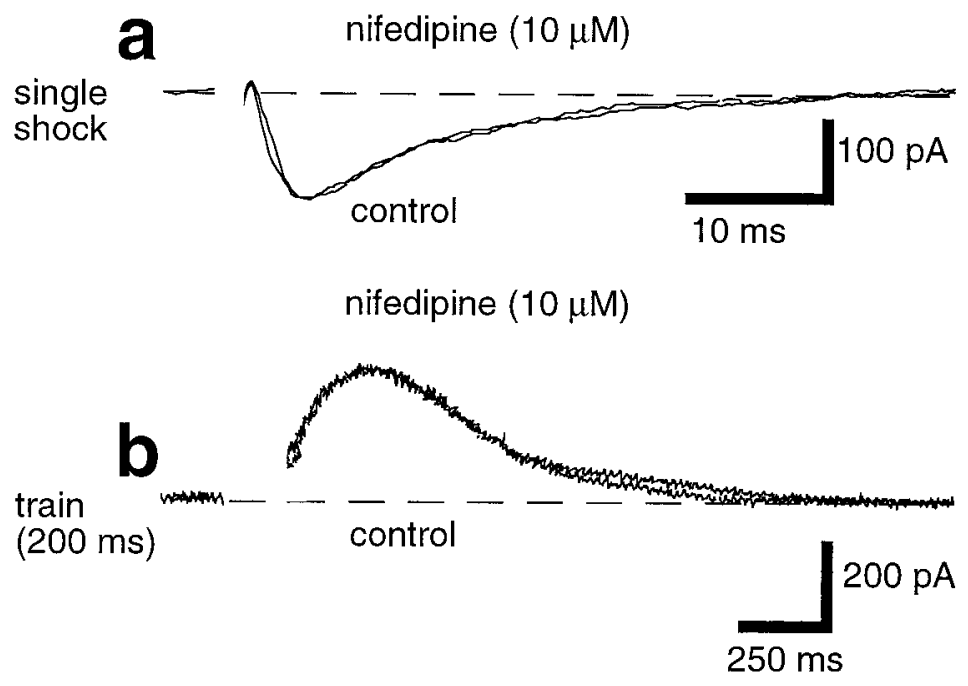

B
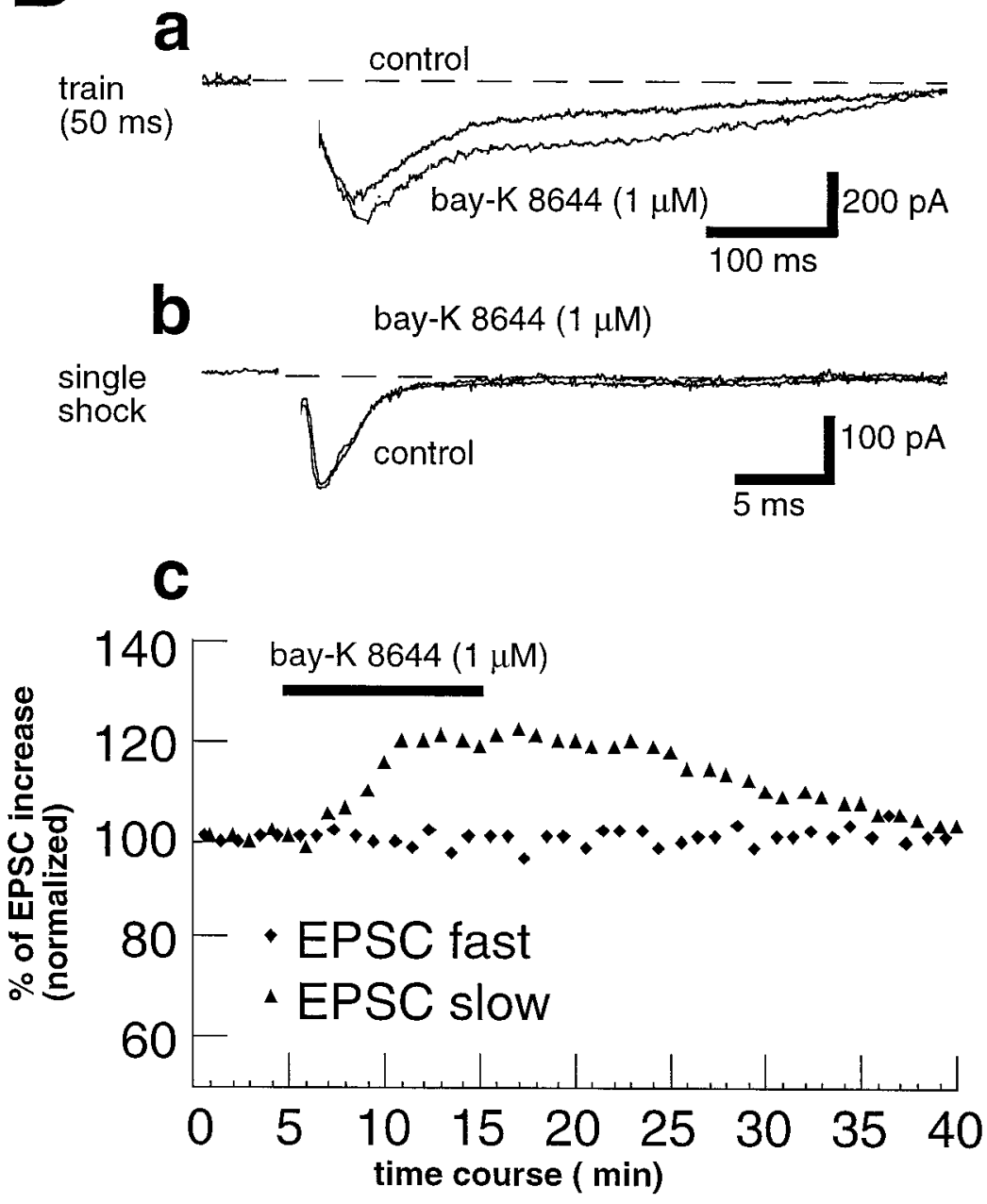

Figure 4. $A$, Nifedipine $(10 \mu \mathrm{M})$ had no effect on the amplitude of the $\mathrm{GABA}_{\mathrm{A}}(a)$ and $\mathrm{GABA}_{\mathrm{B}}(b)$ IPSCs. The $\mathrm{GABA}_{\mathrm{A}}$ current is inward because the recording pipette was filled with a solution containing potassium chloride (see Materials and Methods). $B a, B b$, Superimposed traces showing that the L-type $\mathrm{Ca}^{2+}$ channel agonist Bay-K $8644(1 \mu \mathrm{M})$ increased the $\mathrm{EPSC}_{\mathrm{slow}}$ evoked by a short train $(a)$ but did not augment the $\operatorname{EPSC}_{\text {fast }}(b)$. The EPSC fast and the $\mathrm{EPSC}_{\text {slow }}$ were elicited alternatively in the same cell. $c$, Plot taken from the same dopamine neuron showing the time course of the enhancing effect of Bay-K 8644 on the $\mathrm{EPSC}_{\text {slow. }}$.

\section{L-type calcium channel antagonists reduce the EPSC}

Bath application of the L-type calcium channel antagonists (Janis and Triggle, 1984) nifedipine (1-100 $\mu \mathrm{M})$, nimodipine (1-100 $\mu \mathrm{M})$, and isradipine $(30 \mathrm{~nm}-30 \mu \mathrm{M})$ decreased, in a dosedependent manner, the amplitude of the $\operatorname{EPSC}_{\text {slow }}(n=64)$ (Fig. 2). The $\mathrm{EC}_{50}$ values for the effects of nimodipine, nifedipine, and isradipine were $5.3,6.3$, and $0.63 \mu \mathrm{M}$, respectively. The maximum 
a

control

$30 \mathrm{mV}$

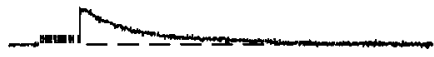

$-60 \mathrm{mV}$
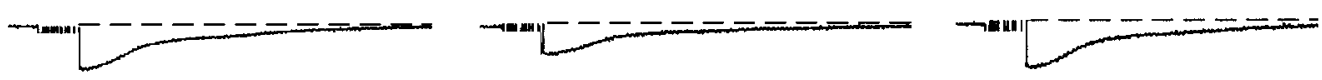

$-100 \mathrm{mV}$
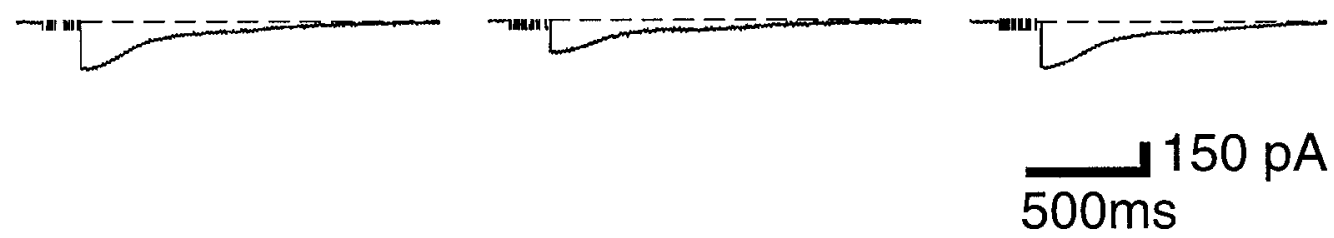

b

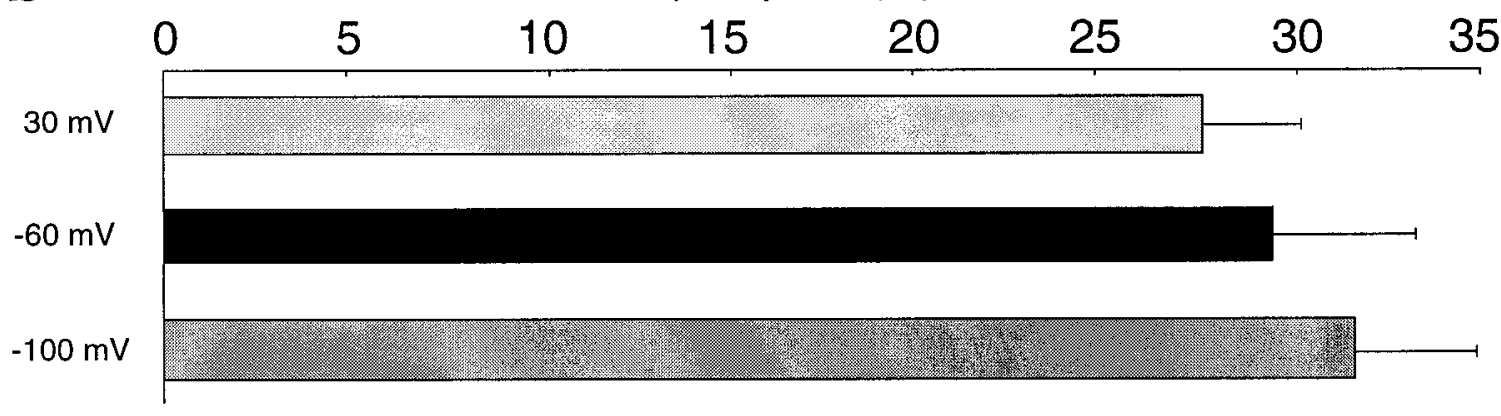

Figure 5. Presynaptic effects of nifedipine. $a$, Changes in the holding potential from $-60 \mathrm{mV}$ to $30 \mathrm{mV}$ or $-100 \mathrm{mV}$ did not affect the depression of the EPSC produced by nifedipine. Typical traces taken form experiments showing the similar degree of inhibition produced by nifedipine (10 $\mu \mathrm{M}) . b$, The horizontal columns show that the percentage of inhibition caused by nifedipine $(10 \mu \mathrm{M})$ at $30 \mathrm{mV},-60 \mathrm{mV}$, and $-100 \mathrm{mV}$ is not statistically different among the three groups of neurons tested $(p>0.05)$. Each column represents an average of at least five cells. To improve space-clamp between proximal somatic and distal dendritic regions, the $I_{\mathrm{h}}$ current was also reduced by extracellular $\mathrm{CsCl}(1 \mathrm{mM})$ during the hyperpolarization.

degree of inhibition was caused by $30 \mu \mathrm{M}$ isradipine $(48.6 \pm 3.1 \%$, $n=5)$. Nifedipine $(100 \mu \mathrm{M})$ and nimodipine $(100 \mu \mathrm{M})$ reduced the slow synaptic current by $42.2 \pm 4.8 \%$ and $36.8 \pm 4.8 \%$, respectively. The depression of the $\mathrm{EPSC}_{\text {slow }}$ induced by the DHPs reached a steady-state in 5-12 min and was washed out in $\sim 15-25 \mathrm{~min}$.

Interestingly, there was a direct correlation between the degree of inhibition of the slow synaptic current and the duration of the stimulation necessary to produce the $\mathrm{EPSC}_{\text {slow }}$. In fact, the re-

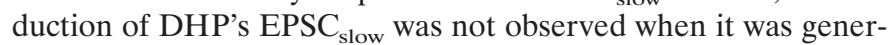
ated by a train of stimuli having a duration $<70 \mathrm{msec}(n=11)$ (Fig. 3). However, when the train of stimuli lasted $>80 \mathrm{msec}$, the DHPs clearly depressed the $\operatorname{EPSC}_{\text {slow }}(n=53)$ (Fig. 3). In another series of experiments, a single stimulus and a train of stimuli (200 msec duration) were delivered alternately on the same presumed dopaminergic neuron to compare the effect of nifedipine on the fast and slow EPSC (Fig. 3Aa,c). Nifedipine (10 $\mu \mathrm{M})$ reduced the $\mathrm{EPSC}_{\text {slow }}$ by $30.1 \pm 2.1 \%(n=4)$, whereas it did not affect the EPSC $_{\text {fast }}$.

The superfusion of the slices with nifedipine $(10-100 \mu \mathrm{M})$ changed neither the amplitude of the IPSC $_{\text {fast }}\left(\mathrm{GABA}_{\mathrm{A}}\right.$ mediated) (Hausser and Yung, 1994) evoked by a single shock $(n=5)$ nor the IPSC $_{\text {slow }}\left(\mathrm{GABA}_{\mathrm{B}}\right.$ mediated) evoked by a train of stimuli of various durations, ranging from 50 to $400 \mathrm{msec}(n=7)$ (Fig. $4 A a, b)$ (Wu et al., 1995). It is also worth noting that the IPSC ${ }_{\text {slow }}$ was evoked (in the presence of APV and CNQX) by the same stimulation protocol that evoked the $\mathrm{EPSC}_{\text {slow }}$ (see Materials and Methods).

\section{Bay-K 8644 enhances the EPSC slow $_{\text {slo }}$}

The application of the L-type $\mathrm{Ca}^{2+}$ channels agonist Bay-K 8644 (1 $\mu \mathrm{M})$ (Nowycky et al., 1985) increased the amplitude of the EPSC $_{\text {slow }}$ evoked by a short train of stimuli (50-70 msec duration) by $21.8 \pm 2.1 \%(n=5)$ but did not affect the $\operatorname{EPSC}_{\text {fast }}$ (Fig. $\left.4 B\right)$. In four experiments, a single stimulus and a train of stimuli (50 msec duration) were also delivered alternately on the same dopaminergic neuron (Fig. 4B). However, when the train of stimuli lasted $>200 \mathrm{msec}$, Bay-K 8644 did not produce any detectable effect on the $\operatorname{EPSC}_{\text {slow }}(n=5)$ (data not shown). Thus, when a strong stimulation activated maximally the presynaptic L-type 

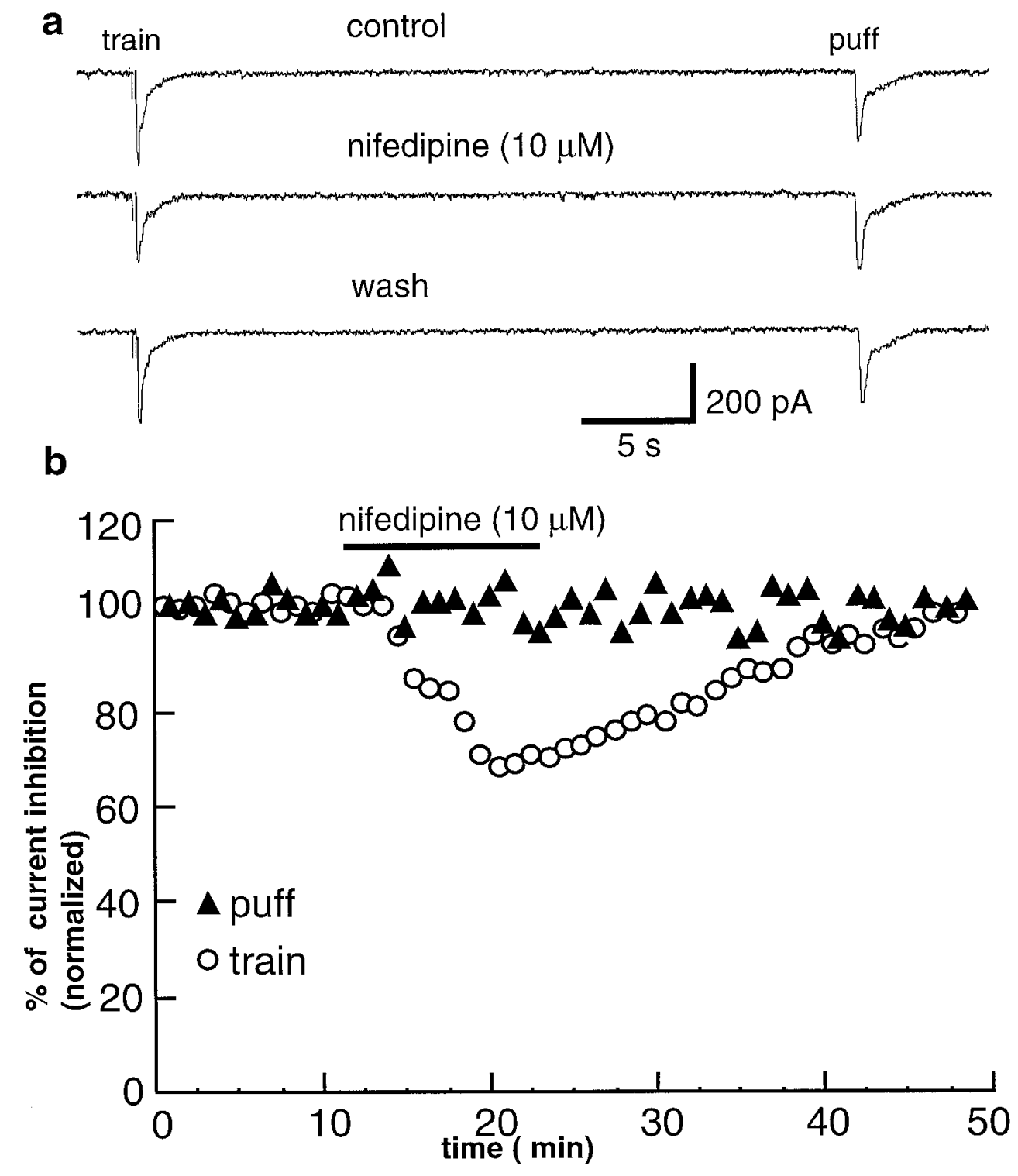

Figure 6. a, Traces from an experiment in which a $200 \mathrm{msec}$ train was given alternately with a 50 msec extracellular ( puff) application of glutamate (1 $\mathrm{mM})$. Nifedipine $(10 \mu \mathrm{M})$ decreased the amplitude of the EPSC $_{\text {slow }}$ but not the inward current evoked by the local application of glutamate. $b$, The plot represents the time course of the experiment shown in $a$.

$\mathrm{Ca}^{2+}$ channels, no further increase of the slow synaptic current was caused by this L-type channel agonist. Furthermore, neither

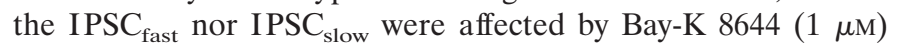
(three cells for each condition; data not shown).

\section{Site of action}

To exclude a possible involvement of postsynaptic L-type calcium channels on the dihydropyridine-mediated depression of the $\mathrm{EPSC}_{\text {slow }}$, additional experiments were performed by holding the potential of the dopaminergic neurons at $+30(n=6)$ and -100 $\mathrm{mV}(n=5)$. Nifedipine $(10 \mu \mathrm{M})$ reduced the $\mathrm{EPSC}_{\text {slow }}$ at $30 \mathrm{mV}$, $-60 \mathrm{mV}$, and $-100 \mathrm{mV}$ to a similar degree (Fig. 5). The percentage reduction was $27.6 \pm 2.7 \%(n=4), 29.4 \pm 3.2 \%(n=4)$, and $31.8 \pm 2.9 \%(n=4)$ at $+30 \mathrm{mV},-60 \mathrm{mV}$, and $-100 \mathrm{mV}$, respectively ( $p>0.05$ ) (Fig. $5 b)$. Furthermore, a train of stimuli lasting $200 \mathrm{msec}$ and pressure-ejected glutamate $(1 \mathrm{~mm})$ were delivered alternately on the same dopaminergic neuron. Nifedipine $(10 \mu \mathrm{M})$ did not modify the inward current caused by locally applied glutamate; however, it did reduce significantly the synaptic current $(p<0.05)$ (Fig. 6), consistent with a presynaptic site of action.

\section{Effects of the blockade of calcium channels subtypes on the EPSC}

When the $\mathrm{N}$ - and $\mathrm{P} / \mathrm{Q}$-type $\mathrm{Ca}^{2+}$ channels were inhibited by the application of $\omega$-conotoxin GVIA ( $1 \mu \mathrm{M}), \omega$-AGA-IVA (200 nM), and $\omega$-conotoxin MVIIC (5 $\mu \mathrm{M})$ (Olivera et al., 1985; Williams et al., 1992; Takahashi and Momiyama, 1993; Boland et al., 1994; Randall and Tsien, 1995), the EPSC fast was almost completely blocked ( $n=4$; data not shown). The $\mathrm{EPSC}_{\text {slow }}$ evoked by a short train of stimuli (50 msec duration) was reduced by $88.2 \pm 6.2 \%$ $(n=3)$ (Fig. $7 A)$. The subsequent application of nifedipine (30 $\mu \mathrm{M})$ did not produce any further effect $(91.3 \pm 2.7 \% ; n=3)$ (Fig. $7 A$ ). The next experiments examined the contribution of L-type calcium channels to the EPSC $_{\text {slow }}$ elicited by a long train of stimuli. The amplitude of the EPSC $_{\text {slow }}$ evoked by a $80-200 \mathrm{msec}$ 
A $\quad 50$ msec train

\section{0 msec train}

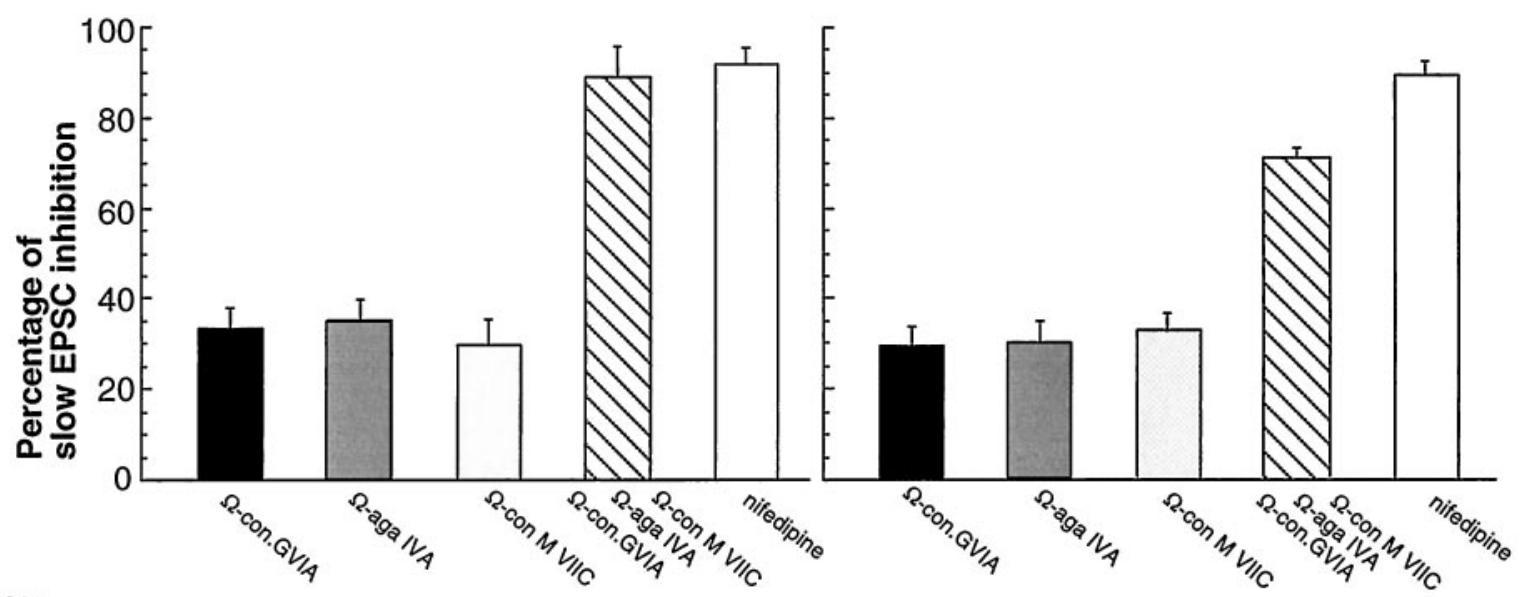

B

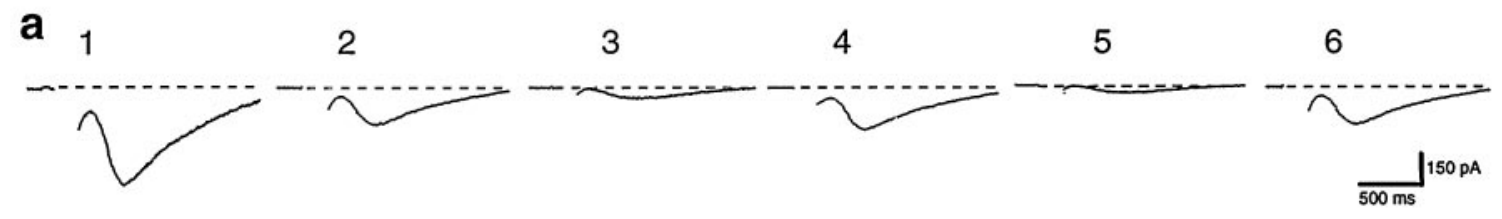

b

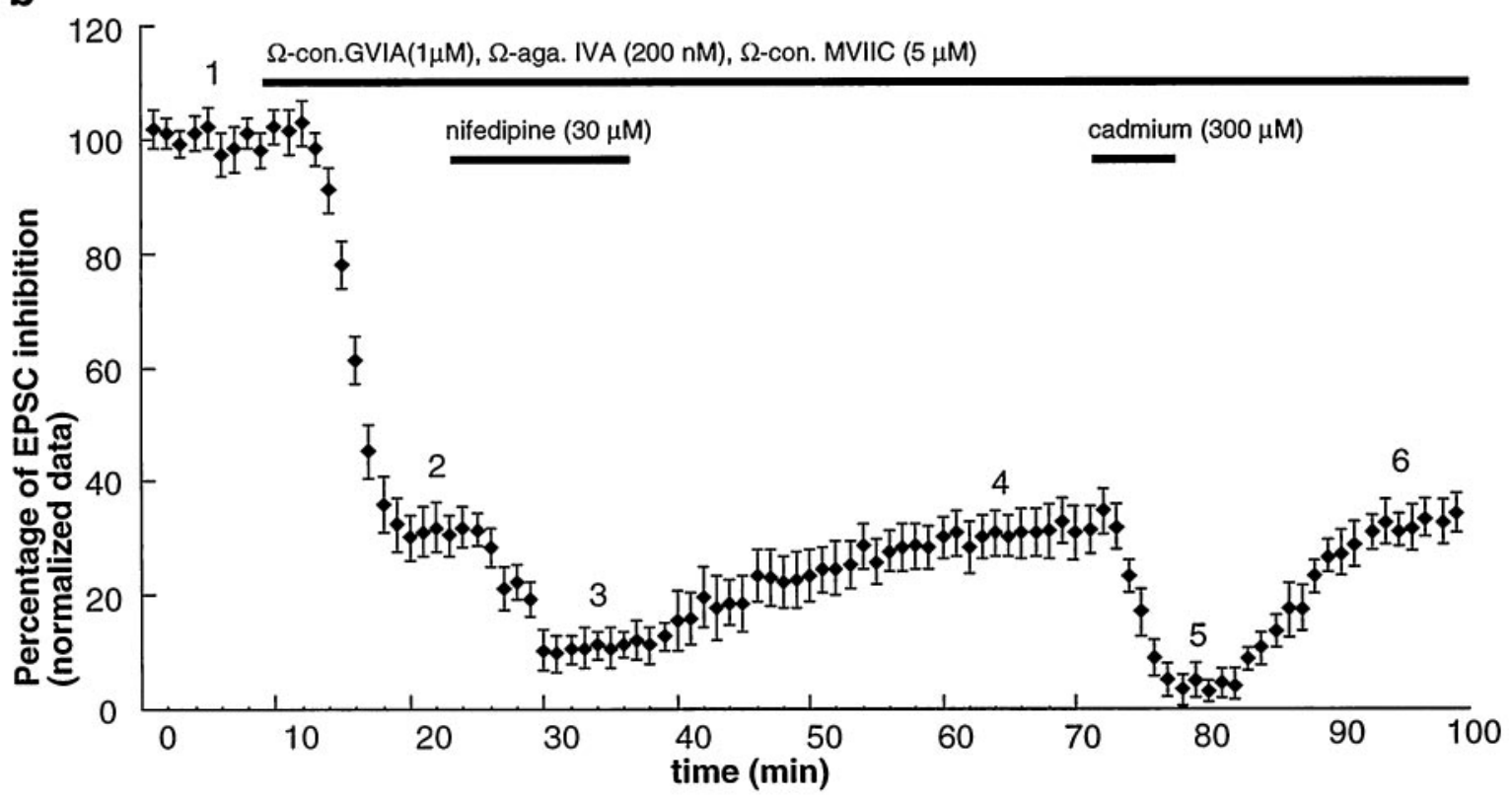

Figure 7. A, The graph shows the depressant effects of $\omega$-conotoxin GVIA ( $1 \mu \mathrm{M})$, $\omega$-AGA-IVA (200 nM), and $\omega$-conotoxin MVIIC (5 $\mu \mathrm{M})$ on the EPSC $_{\text {slow }}$ evoked by a short train of stimuli. Note that nifedipine $(30 \mu \mathrm{M})$ added to the three toxins did not depress the synaptic current. $A, B$, In the presence of $\omega$-conotoxin GVIA (1 $\mu \mathrm{M})$, $\omega$-AGA-IVA (200 nM), and $\omega$-conotoxin MVIIC (5 $\mu \mathrm{M})$, nifedipine (30 $\mu \mathrm{M})$ reversibly depressed the residual EPSC $_{\text {slow. }}$ The residual synaptic current recorded after the treatment with the toxins was blocked by cadmium $(300 \mu \mathrm{M})$. Ba, Sample records of a cell

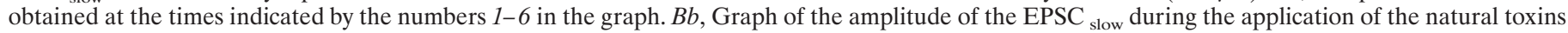
nifedipine $(30 \mu \mathrm{M})$ and cadmium $(300 \mu \mathrm{M})$. Each point is an average of four experiments performed on four different slices.

train of stimuli was reduced by the application of the three toxins by $71.1 \pm 2.3 \%(n=4)$ (Fig. $7 A)$. In contrast to the cells stimulated with a short train, the addition of nifedipine $(30 \mu \mathrm{M})$ produced a further reduction to $89.2 \pm 2.8 \% ; n=4$ ) (Fig. $7 A, B)$. $\mathrm{Cd}^{2+}(300 \mu \mathrm{M})$ had a similar but more prominent effect on the residual $\operatorname{EPSC}_{\text {slow }}(n=4)$. In three experiments, the concentration of $\omega$-conotoxin GVIA, $\omega$-AGA IVA, and $\omega$-conotoxin MVIIC was raised from 1 to $1.5 \mu \mathrm{M}$, from 200 to $300 \mathrm{nM}$, and from 5 to $7 \mu \mathrm{M}$, respectively. However, the depression of the residual $\mathrm{EPSC}_{\text {slow }}$ caused by nifedipine $(30 \mu \mathrm{M})$ was similar 
$(93.1 \pm 2.9 \% ; p>0.05)$ to that observed with the lower concentrations of toxins.

\section{DISCUSSION}

Our results indicate that high frequency stimulation of the ventral mesencephalon reveals a specific role for L-type $\mathrm{Ca}^{2+}$ channels in the release of excitatory amino acids on dopaminergic neurons. The observation that the $\mathrm{EPSC}_{\text {slow }}$ was reduced but not blocked by $\omega$-conotoxin-GVIA, $\omega$-agatoxin-IVA, and $\omega$-conotoxin MVIIC not only demonstrates the importance of the $\mathrm{N}$ - and $\mathrm{P} / \mathrm{Q}$-type $\mathrm{Ca}^{2+}$ channels in the release of EAAs, but it also confirms previous biochemical and electrophysiological findings showing that a part of the release of glutamate in the brain is resistant to $\mathrm{N}$ - and $\mathrm{P} / \mathrm{Q}$-type $\mathrm{Ca}^{2+}$ channel antagonists (Brown et al., 1986; Turner et al., 1992; Huston et al., 1995). Thus, in contrast to a single or a short train, a prolonged high-frequency stimulation may activate a sufficient number of L-type $\mathrm{Ca}^{2+}$ channels by producing a prolonged depolarization of the presynaptic terminals. Consequently, the influx of $\mathrm{Ca}^{2+}$ ions through them could significantly participate in the exocytosis of EAAs on the dopaminergic cells. The fact that the DHPs do not reduce the excitatory transmission mediated either by single electrical stimuli or by a short-stimulus train supports a more specific function for L-type calcium channels in controlling the excitatory synaptic events caused by a long sequence of action potentials. In fact, as observed in other parts of the CNS, the influx of calcium during a weak stimulation of presynaptic terminals is certainly controlled by the cooperative activation of $\mathrm{N}$ - and $\mathrm{P} / \mathrm{Q}$-type channels (Luebke et al., 1993; Mintz et al., 1995) but not by L-type channels that require a stronger depolarization to open.

It is conceivable that the naturally occurring release of excitatory neurotransmitters on the dopaminergic neurons is not only related to the invasion of the synaptic terminals by a single action potential but also by a sequence of spikes. Indeed, the sustained release of EAAs from cortical cells has an important role in regulating the type of firing of the dopaminergic cells (bursting vs pacemaker) (Grenhoff et al., 1988; Overton and Clark, 1992), the extracellular level of dopamine (Taber and Fibiger, 1995a,b), and the activity of dopaminergic neurons to salient stimuli (Schultz, 1992). The cortical and subthalamic neurons that release EAAs on the dopaminergic cells are certainly able to maintain a high rate of repetitive firing (Connors et al., 1982; Stafstrom et al., 1985; Smith and Grace, 1992; Overton and Greenfield, 1995; Kreiss et al., 1997) and to depolarize their excitatory terminals for a longer time. The biophysical properties of L-type calcium channels (timeand voltage-dependence) allow them to be active under conditions of repetitive stimulation. Thus, the time-, voltage-, and use-dependent properties of DHPs on L-type calcium channels (Sanguinetti and Kass, 1984) could account for the depression

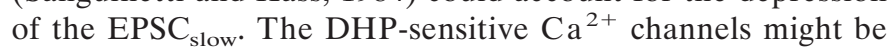
localized on all the different sources of EAAs that project to the ventral mesencephalon (Christie et al., 1985; Kita and Kitai, 1987; Sesack and Pickel, 1992; Lavoie and Parent, 1994). Alternatively, only selected nerve terminals of a more heterogeneous population of afferents might bear L-type channels that regulate EAA exocytosis. It is worth mentioning that other neurons from various regions of the CNS are able to fire in a burst or in a sustained manner. For this reason, it could be postulated that the action of L-type $\mathrm{Ca}^{2+}$ channels on the slow synaptic event observed on the dopaminergic neurons might occur in other areas of the brain.
All three DHP antagonists used in this study depressed in a reversible manner the $\mathrm{EPSC}_{\text {slow }}$ in a micromolar range. This is a rather peculiar effect, because micromolar doses of DHP antagonists do not usually change fast synaptic transmission in the dopaminergic cells and in various central neurons in in vitro conditions (Takayashi and Momiyama, 1993; Wheeler et al., 1994; Dunlap et al., 1995; Sim and Griffith, 1996; Poncer, 1997). It is also interesting to note that, as observed in other areas of the brain, the fast and slow inhibitory synaptic currents were not affected by the DHP antagonists. This suggests that the exocytosis of glutamate/aspartate but not that of GABA is controlled by L-type $\mathrm{Ca}^{2+}$ channels during a sustained stimulation. Because the DHPs reduce only the long EPSC $_{\text {slow }}$ but leave unaffected the amplitude and duration of the short $\mathrm{EPSC}_{\text {slow }}$ and the $\mathrm{IPSC}_{\text {slow }}$, it is unlikely that a nonspecific depression of excitability of presynaptic fibers could account for the reduced release of transmitter after a train of stimuli. Thus, L-type calcium channels could, during high frequency stimulation, modulate excitatory transmission to dopaminergic cells. The manipulation of the holding potential of the dopaminergic cells from -100 to $+30 \mathrm{mV}$ indicates that postsynaptic voltage-dependent dihydropyridine-sensitive calcium channels are not required for nifedipine action on the $\mathrm{EPSC}_{\text {slow }}$. Although at $-100 \mathrm{mV}$ the L-type calcium channels should be closed, at $30 \mathrm{mV}$ the contribution of postsynaptic L-type channels to the synaptic event should be minimal (Cardozo and Bean, 1995). The reversal of the EPSC indicates that adequate voltage-clamp was maintained. These sets of experiments together with those in which glutamate was locally applied imply that L-type presynaptic calcium channels are involved.

\section{Conclusions}

In conclusion, the experiments described in the present paper demonstrate that L-type calcium channels play an important role in triggering the release of excitatory neurotransmitters on the dopaminergic neurons of the ventral mesencephalon. Thus, the activation of presynaptic boutons by a relatively long burst of action potentials could open not only the $\mathrm{N}$ - and P/Q-type but also the L-type $\mathrm{Ca}^{2+}$ channels that participate in controlling the strength of excitation of the dopaminergic neurons.

Our data also suggest a rationale for the pharmacological manipulation of the EAA inputs to the dopaminergic neurons by drugs that modulate presynaptic L-type calcium channels in neurological and psychiatric disorders involving the dopamine system.

\section{REFERENCES}

Augustine GJ, Charlton MP, Smith SJ (1987) Calcium action in synaptic transmitter release. Annu Rev Neurosci 10:633-693.

Bean BP (1989) Classes of calcium channels in vertebrate cells. Annu Rev Physiol 51:367-384.

Boland LM, Morrill JA, Bean BP (1994) Omega-conotoxin block of N-type calcium channels in frog and rat sympathetic neurons. J Neurosci 14:5011-5027.

Bonci A, Williams JT (1997) Increased probability of GABA release after chronic morphine treatment. J Neurosci 17:678-689.

Brown AM, Kunze DL, Yatani A (1986) Dual effects of dihydropyridines on whole cell and unitary calcium currents in single ventricular cells of guinea-pig. J Physiol (Lond) 379:495-514.

Cardozo DL, Bean BP (1995) Voltage-dependent calcium channels in a rat midbrain dopamine neurons: modulation by dopamine and $\mathrm{GABA}_{\mathrm{B}}$ receptors. J Neurophysiol 74:1137-1148.

Christie MJ, Bridge S, James LB, Beart PM (1985) Excitotoxins lesion 
suggest an aspartatergic projection from rat medial prefrontal cortex to ventral tegmental area. Brain Res 333:169-172.

Connors BW, Gutnick MJ, Prince DA (1982) Electrophysiological properties of neocortical neurons in vitro. J Neurophysiol 48:1302-1320.

Dunlap K, Luebke JI, Turner TJ (1995) exocitotic $\mathrm{Ca}^{++}$channels in mammalian central neurons. Trends Neurosci 18:89-98.

Grace AA, Onn SP (1989) Morphology and electrophysiological properties of immunocytochemically identified rat dopamine neurons recorded in vitro. J Neurosci 9:3463-3481.

Grenhoff J, Ugedo L, Svennson TH (1988) Firing patterns of midbrain dopamine neurons: diversity in intrinsic differences between A9 and A10. Acta Physiol Scand 134:271-284.

Hausser MA, Yung WH (1994) Inhibitory synaptic potentials in guinea pig substantia nigra dopamine neurones in vitro. J Physiol (Lond) 479:401-422.

Horne AL, Kemp JA (1991) The effect of $\omega$-conotoxin GVIA on synaptic transmission within the nucleus accumbens and hippocampus of the rat in vitro. Br J Pharmacol 103:1733-1739.

Huston E, Cullen GP, Burley JR, Dolphin AC (1995) The involvement of multiple calcium channel sub-types in glutamate release from cerebellar granule cells and its modulation by $\mathrm{GABA}_{\mathrm{B}}$ receptor activation. Neuroscience 68:465-478.

Janis D, Triggle DJ (1984) 1,4-dihydropyridine calcium channel antagonists and activators: a comparison of binding characteristics with pharmacology. Drug Dev Res 4:257-274.

Johnson SW, North RA (1992) Two types of neurones in the rat ventral tegmental area and their synaptic inputs. J Physiol (Lond) 450:455-468.

Kamiya H, Sawada S, Yamamoto C (1988) Synthetic $\omega$-conotoxin blocks synaptic transmission in the hippocampus in vitro. Neurosci Lett 91:84-88.

Katz B, Miledi R (1969) Tetrodotoxin-resistant electric activity in presynaptic terminal. J Physiol (Lond) 203:459-487.

Kita H, Kitai ST (1987) Efferent projection of the subthalamic nucleus in the rat: light and electron microscopic analysis with the PHA-L method. J Comp Neurol 260:435-452.

Kita T, Kita H, Kitai ST (1986) Electrical membrane properties of rat substantia nigra compacta neurons in an in vitro slice preparation. Brain Res 372:21-30.

Kreiss DS, Mastropietro CW, Rawji SS, Walters JR (1997) The response of subthalamic nucleus neurons to dopamine receptor stimulation in a rodent model of Parkinson's disease. J Neurosci 17:6807-6819.

Kullman DM, Perkell DJ, Manabe,T, Nicoll RA (1992) $\mathrm{Ca}^{++}$entry via post-synaptic voltage-sensitive $\mathrm{Ca}^{++}$channels can transiently potentiate excitatory synaptic transmission in the hippocampus. Neuron 9:1175-1183.

Lacey MG, Mercuri NB, North RA (1989) Two cell types in rat substantia nigra zona compacta distinguished by membrane properties and the actions of dopamine and opioids. J Neurosci 9:1233-1241.

Lavoie B, Parent A (1994) Pedunculopontine nucleus in the squirrel monkey: cholinergic and glutamatergic projections to the substantia nigra. J Comp Neurol 344:232-241.

Le Moal M (1995) Mesocorticolimbic dopaminergic neurons. In: Psychopharmacology: the fourth generation of progress (Bloom FE, Kupfer DJ, eds), pp 283-294. New York: Raven.

Lemos JR, Nowycky MC, (1989) Two types of calcium channels coexist in peptide-releasing vertebrate nerve terminals. Neuron 2:1419-1426.

Llinàs R, Steinberg IZ, Walton K (1981) Relationship between presynaptic calcium current and postsynaptic potential in squid giant synapse. Biophys J 33:323-352.

Llinàs R, Sugimori M, Lin JW, Cherskey B (1989) Blocking and isolation of a $\mathrm{Ca}^{++}$channel from neurons in mammals and cephalopods utilizing a toxin fraction (FTX) from funnel-web spider poison. Proc Natl Acad Sci USA 86:1689-1693.

Lopez MG, Villaroya M, Lara B, Martinez Sierra R, Albillos A, Garcia AG, Gandia L (1994) Q- and L-type $\mathrm{Ca}^{++}$channels dominate the control of secretion in bovine chromaffin cells. FEBS Lett 349:331-337.

Luebke JI, Dunlap K, Turner TJ (1993) Multiple calcium channel types control glutamatergic synaptic transmission in the hippocampus. Neuron 11:895-902.

Mercuri NB, Bonci A, Calabresi P, Stratta F, Bernardi G (1995) Properties of the hyperpolarization-activated cation current $I_{\mathrm{h}}$ in rat midbrain dopaminergic neurons. Eur J Neurosci 7:462-469.

Mercuri NB, Grillner P, Bernardi G (1996) N-methyl-D-aspartate receptors mediate a slow excitatory post-synaptic potential in the rat midbrain dopaminergic neurons. Neuroscience 74:785-792.
Miller RJ (1987) Multiple calcium channels and neuronal function. Science 235:46-52.

Mintz IM, Venema VJ, Swiderek KM, Lee TD, Bean BP (1992) P-type calcium channels blocked by the spider toxin $\omega$-Aga-IVA. Nature 355:827-829.

Mintz IM, Sabatini BL, Regehr WG (1995) Calcium control of transmitter release at a cerebellar synapse. Neuron 15:675-688.

Nowycky MC, Fox AP, Tsien RW (1985) Long-opening mode of gating of neuronal calcium channels and its promotion by the dihydropyridine calcium agonist Bay K 8644. Proc Natl Acad Sci USA 82:2178-2182.

Olivera BM, Gray WR, Zeikus R, McIntosh JM, Varga J, Rivier J, de Santos V, Cruz LJ (1985) Peptide neurotoxins from fish-hunting conesnails. Science 230:1338-1343.

Overton P, Clark D (1992) Iontophoretically administered drugs acting at the $N$-methyl-D-aspartate receptor modulate burst firing in A9 dopamine neurons in the rat. Synapse 10:131-140.

Overton PG, Greenfield SA (1995) Determinants of neuronal firing pattern in the guinea-pig subthalamic nucleus: an in vivo and in vitro comparison. J Neural Transm Park Dis Dement Sect 10:41-54.

Poncer JC (1997) Either N- or P-type calcium channels mediate GABA release at distinct hippocampal inhibitory synapses. Neuron 18:463-472.

Randall A, Tsien RW (1995) Pharmacological dissection of multiple types of calcium channel currents in rat cerebellar granule cells. J Neurosci 15:2995-3012.

Reuter H (1996) Diversity and function of presynaptic calcium channels in the brain. Curr Opin Neurobiol 6:331-337.

Sanguinetti MC, Kass RS (1984) Voltage-dependent block of calcium channels current in the calf cardiac Purkinje fiber by dihydropyridine calcium channel antagonists. Circ Res 55:336-348.

Schultz W (1992) Activity of dopamine neurons in the behaving primate. Semin Neurosci 4:129-138.

Seabrook GR, Adams DJ (1989) Inhibition of neurally-evoked transmitter release by calcium channel antagonists in rat parasympathetic ganglia. Br J Pharmacol 97:1125-1136.

Seeman P (1995) Dopamine receptors: clinical correlates. In: Psychopharmacology: the fourth generation of progress (Bloom FE, Kupfer DJ, eds), pp 295-302. New York: Raven.

Sesack SR, Pickel VM (1992) Prefrontal cortical efferents in the rat synapse on unlabeled neuronal target of catecholamine terminals in the nucleus accumbens septi and on dopamine neurons in the ventral tegmental area. J Comp Neurol 320:145-160.

Shen KZ, Johnson SW (1997) A slow excitatory postsynaptic current mediated by G-protein-coupled metabotropic glutamate receptors in a rat ventral tegmental dopamine neurons. Eur J Neurosci 9:48-57.

Sim JA, Griffith WH (1996) Muscarinic inhibition of glutamatergic transmission onto rat magnocellular basal forebrain neurons in a thin slice preparation. Eur J Neurosci 8:880-891.

Simmons ML, Terman GW, Gibbs SM, Chavkin C (1995) L-type calcium channels mediate dynorphin neuropeptide release from dendrites but not axons of hippocampal granule cells. Neuron 14:1265-1272.

Smith ID, Grace AA (1992) Role of subthalamic nucleus in the regulation of nigral dopamine neuron activity. Synapse 12:287-303.

Stafstrom CE, Schwindt PC, Chubb MC, Crill WE (1985) Properties of persistent sodium conductance and calcium conductance of layer $\mathrm{V}$ neurons from cat sensory-motor cortex in vitro. J Neurophysiol 53:153-170.

Taber MT, Fibiger HC (1995a) Electrical stimulation of the prefrontal cortex increases dopamine release in the nucleus accumbens of the rat: modulation by metabotropic glutamate receptors. J Neurosci 15:3896-3904.

Taber MT, Fibiger HC (1995b) Cortical regulation of subcortical dopamine release: mediation via the ventral tegmental area. J Neurochem 65:1407-1410.

Takahashi T, Momiyama A (1993) Different types of calcium channels mediate central synaptic transmission. Nature 366:156-158.

Takibana M, Okada T, Arimura T, Kobayashi K, Piccolino M (1993) dihydropyridine-sensitive calcium current mediates neurotransmitter release from bipolar cells of the goldfish retina. $\mathrm{J}$ Neurosci 13:2898-2909.

Turner TJ, Adams ME, Dunlap K (1992) Multiple calcium channel types coexist to regulate synaptosomal neurotransmitter release. Proc Natl Acad Sci USA 90:9518-9522.

Von Gersdorff H, Matthews G (1996) Calcium-dependent inactivation 
of calcium current in synaptic terminals of retinal bipolar neurons. J Neurosci 16:115-122.

Wheeler DB, Randall A, Tsien RW (1994) Roles of N-type and Q-type calcium channels in supporting hippocampal synaptic transmission. Science 264:107-111.

Williams ME, Brust PF, Feldman DH, Patthi S, Simerson S, Maroufi A, Mc Crue AF, Velicelebi G, Ellis SB, Harpold MM (1992) Structure and functional expression of an omega-conotoxin-sensitive human N-type calcium channel. Science 257:389-395.

Wright CE, Angus JA (1996) Effects of N-, P- and Q- type neuronal calcium channels antagonists on mammalian peripheral neurotransmission. Br J Pharmacol 119:49-56.
Wu Y, Mercuri NB, Johnson SW (1995) Presynaptic inhibition of $\gamma$-amino-butyric acid B-mediated synaptic currents by adenosine recorded in vitro in midbrain dopamine neurons. J Pharmacol Exp Ther 273:576-581.

Yung WH, Hausser MA, Jack JJB (1991) Electrophysiology of dopaminergic and non-dopaminergic neurons of the guinea-pig substantia nigra pars compacta in vitro. J Physiol (Lond) 436:643-667.

Zhang JF, Randall AD, Ellinor PT, Horne WA, Sather WA, Tanabe T, Schwartz TL, Tsien RW (1993) Distinctive pharmacology and kinetics of cloned neuronal calcium channels and their possible counterparts in mammalian CNS neurons. Neuropharmacology 32:10751088. 